\title{
Teaching Reform and Exploration for General Colleges' Fundamental Accounting
}

\author{
Xiaolei Zhang \\ Shenyang Aerospace University College of Economics and Management 110136
}

\begin{abstract}
Keywords: Fundamental accounting; Teaching; Existing problems; Reform measures
\end{abstract}
\begin{abstract}
The teaching reform of fundamental accounting should pay attention the highlighted problems at present, adapt to the development of subjects, constantly update teaching materials, and teaching content. What's more, they should also take advantage of he multimedia teaching methods to fully play the initiative of students in the course learning. More over, it should also integrate teaching method, advanced theory, and practice.
\end{abstract}

\section{Introduction}

Along with the launch of Accounting Criteria for Enterprises, Explanation for Accounting Criteria for Enterprises 2008 and Explanation for Accounting Criteria for Enterprises 2010, we can comprehensively master the accounting principles, deeply understand the core rules of accounting, better implement accounting principles, and further improve the accounting information quality. At the same time it can also make the accounting system of China close to the international ones. Under the environment of economic globalization, accountants should not only be equipped with abundant professional knowledge, but also professional analysis ability and judgment ability. More over, they should have a strong sense of market economy and strong ability to adapt to society as well as the ability to be better engaged in accounting, auditing, and taxes. Colleges are the cradle to cultivate talent, so in order to cultivate high quality accounting talents, teachers should try their best in terms of teaching contents and methods. However, due to the limitation of education systems, teaching principles, and teaching methods, fundamental accounting can not play a good role in guiding primary accounting learners. In the following, the author will show some of his views based on his work according to experience in fundamental accounting reform.

\section{Existing Problems in Teaching Fundamental Accounting}

Too Many Teaching Materials with Different Qualities. Almost all publish offices in financial fields has the teaching material of fundamental accounting, therefore it is diverse, but there are few classic ones, which can really work.

Single Teaching Mode and Outdated Ideas. Some teachers, especially old teachers, they can not master the essence of the text book and are unable to adopt modern teaching methods. Therefore, their classes are boring and it is difficult to follow.

Students do not Have a Theoretical Framework and It Is Difficult for Them to Form Accounting Thoughts. Fundamental accounting is a totally new subject for students and for those with zero background in accounting, it will be very difficult for them to form a relevant framework and ideas in a short time. Therefore, teachers should think more about it and adopt effective measures for students to accept according to their personal characteristics.

\section{Teaching Reform of Fundamental Accounting}

Correctly Master Teaching Contents. Good textbooks are good teachers and therefore teaching materials are very important course resources, which can be beckoned as important carriers to implement their teaching goals. At present there are too many editions of fundamental accounting, but their contents can be concluded into two types: one has no theoretical knowledge and one has too much. In real teaching it is not difficult to find out that if we combine accounting concept, function, and hypothesis together and imbue students with all of this knowledge, they will feel too 
much pressure and lose enthusiasm and passion for this course. In the contrast, as teachers of fundamental accounting, we should be able to master the teaching contents according to the real condition of students, so that we can be fully prepared while teaching.

Adapt to the Requirement of Subject Development and Constantly Update Teaching Contents. Fundamental accounting is a subject which is a subject that is theoretical, scientific, and practical, but at the same time it is always developed. As a result teachers should be equipped with the ability to constantly learn and update their knowledge, so that they can make fundamental changes because of accounting principle adjustments. If teachers cannot continuously update the knowledge system, they will convey incorrect information in class.

Clear the Teaching Focus and Difficulties Based on Teaching Targets. The teaching target of fundamental accounting is that students are able to professionally carry out accounting auditing, prepare accounting reports, and analyze economic phenomena. However, while carrying out classes teachers pay more attention to the preparation of accounting entries. They hold the idea that if students can deal with economic business correctly they can learn fundamental accounting well. They didn't emphasis the goal of accounting entries and it's function in the whole auditing system. As far as the author is concerned, the fundamental accounting teaching should take the ability of making simple accounting materials, preparing balance sheets, income statements, cash flow statements as the highest requirement. What's more, they should also be able to naturally combine the auditing and accounting information to help students be aware of the details of each process. Furthermore, they should adhere to the principle of deducting the reason based on results and conclude based on reason so as to realize the teaching goal and lay a good foundation for practice.

Adopt Network Platform to Broaden Students' Horizon. Even though class is the main play for students to learn, they still have to do a lot of extra after class reading and conduct practical training. For example, we recommend www.caidaos.com to students, while what the teachers need to do is register "My class" and at the same time prepare interesting topics related to the teaching contents. After that, students can join in the class to carry out training and self evaluation. For example how to correctly write a check, and value added tax special invoice to let them practice and carry out self evaluation. Based on this operation, they cannot only consolidate knowledge, but also practice as if in the real world, which can greatly improve their passion to learn this course.

\section{Teaching Method Reform}

Adhere To Human Orientation To Fully Play The Initiative Of Students In Class. Traditional teaching fundamental accounting takes teacher as the focus. In class, teachers are protagonists while students can only accept passively without initiative. This kind of overly rigid teaching methods leads to passive learning. In fact, students are the most active element in the process of teaching, and should be deemed as the subject of teaching activities. Effective classroom teaching of fundamental accounting should adhere to the main body of students respect student's personality and stimulate students ' learning interest. Therefore, in the process of teaching, we should grasp the psychological characteristics of students, take advantage of cutting-edge knowledge and theory to attract students ' attention, so as to let them participate in classroom activities, and create a harmonious atmosphere in the classroom.

Introduce Case Teaching to Combine Both Theory and Practice. Classroom teaching should combine theoretical lectures and practice for example when we talk about accounting certificate, we introduce basic concepts, theories, and then we should directly make them fill out relative papers to find out problems, and meanwhile cultivate their habits of being serious and realistic. Based on this, we combine knowledge inculcation, ability cultivation and quality education together, which can greatly integrate theory and practice, and achieve the purpose of imparting knowledge and educating people.

Case study as a new teaching method is inevitably helpful to improve teaching effect and solve realistic problems. Case teaching takes reality as the background to describe one or several typical cases to let people conclude the enlightenment with the help of multimedia etc. For example, in the chapter of auditing for the manufacturing process of industrial enterprises, we pay attention to the 
three sectors of production, supply, integrated marketing to simulate the process of raising funds, purchasing, production and sales with real cases. By this way, it is easy for students to understand and accept which can also stimulate their interest. At present, most colleges take theoretical teaching as the first important thing and practical training as the second. As a result, theoretical teaching and practical training are separated from time and space, which can not be linked together. To strengthen the percent of practical training, and improve students' application ability has become the consensus of people. Of course, taking into account the students ' knowledge is relatively shallow, teachers should make simple and operable cases for students to understand.

Practical teaching includes cognition practice, simulation of basic accounting, financial accounting simulated practice and accounting computerization simulated practice. Concerning cognition practice, students should visit the enterprise production processes, and the financial sector to let professionals to introduce the accounting process. If it is possible, we should allow students to take one week internship in the accounting department. However, teachers should choose practical business in advance to let students learn how to fill out certificate, bookkeeping, reconciliation, resolution of billing and finally prepare accounting statement. What's more, they can also let students set their economic business to carry out business accounting. Computerized accounting computerization simulated practice should be completed in the laboratory to let students practice and let them operate multi teaching software to cultivate students' ability to relate theory with practice so that they can be adapted to the society quickly with practical skills.

An Innovative Teaching Program Is Required. Accounting is a science closely related to social and economic activities. Economic policies adjustment, management system reform will lead to the adjustment and updating of fundamental accounting. In recent years, non-stable structures of accounting is highlighted. The teaching program can be used for both teachers and students. So, besides clear requirement on this course, we should also update the course based on subject development to cultivate students' ability. What's more, we should also clear the relation between this course and other course to optimize the class teaching contents and strengthen after-school activities. Furthermore, it is also necessary to stimulate students' enthusiasm to learn with proper methods to cultivate their comprehensive abilities.

Fully Play the Function of Multimedia in Teaching. Teachers play the role in traditional fundamental accounting teaching to describe and explain accounting theories. This method is in shortage of motivation and beauty and cannot trigger students' interest and show the features of this course. In the contrast, multimedia teaching can make up for these demerits because diverse information will bring more sensory stimulations including a wealth of visual and auditory to satisfy different needs of students with different thoughts. For example, the chapter of enterprise management and production processes will be kind of boring, but with the assistance of multimedia demonstration, students are able to directly master the management mode and production process. Therefore, multimedia can make students directly master accounting principles.

Reform the Organization Method of Teaching Contents. "Fundamental accounting is a course which is theoretical, practical and professional. According to the characteristics of this course, we should change the teaching way from single inculcation to enlightening teaching such as classroom practice, visiting, discussion, on-site teaching, situational teaching and case teaching with demonstration in the multimedia classroom. In addition, concerning filling out accounting certificate, bookkeeping, reconciliation, resolution of billing and correcting, we can ask them to practice after the demonstration so as to trigger their passion and meanwhile improve their ability to analyze and solve problems. By the way, teachers should be dignified in appearance with clear voice and passion to explain profound theories in simple language and combine theory with practice. Based on this, they are able to make the class lively and create good interaction.

A Set of Scientific Assessment Is Required. The assessment is to guide, evaluate and encourage students' learning. We should focus on the information feedback of assessment on teaching effect to improve the work efficiency to pay attention to students' ability to analyze and solve problems. Traditional assessment on accounting can be carried out based on computer besides 
traditional sheet answer so as to make separation of teaching and testing. In addition, we can also evaluate the teaching effect based on the computer.

\section{Conclusion}

To cultivate professional, high quality accounting talents adapted to the economic development is the mission of every educators, which is the key to develop our accounting field. What's more, to change the current talent cultivation mechanism, update teaching ideas, perfect teaching equipment, strengthen students' professional skills and quality will make fundamental accounting step into a new stage.

\section{References}

[1] Wang Benqiang, Wu Xufen, Wei Zhubao. Demerits of current Fundamental Accounting and new teaching material proposition [J]. Finance and Accounting Monthly, 2010.9.

[2] Miao Qijun. Reform and innovation of fundamental accounting [J]. Friends of Accounting, 2010.1.

[3] Hu Lingyan. Discuss on the teaching reform on Fundamental Accounting for higher vocational education [J]. China Township Enterprises Accounting, 2010.1.

[4] Chen Liming. Brief talk on the elementary course of fundamental accounting [J]. Occupation, 2010.2 .

[5] Liu Xuanhong. Discuss on the teaching method of Fundamental Accounting [J]. Science \& technology Information, 2010. 17.

[6] Meng Xiangying, Tan Xuhong. Thoughts on the classroom teaching of Principles of Accounting [J]. Continue Education Research, 2008; (10): 16-17.

[7] Li Yunmei. Exploration on the course teaching methods of accounting [J]. CO-Operative Economy \& Science. 2010; (24): 125-127.

[8] Hao Yingjin. Discuss on the accounting teaching for applied colleges based on practice orientation [J]. Manager, 2010; (22): 336-337

[9] Zhao Xinyan. Discuss on the fundamental accounting teaching for non-accounting majors [J].China Management Informationization, 2010; (23);78-79.

[10] Hou Baijing. Design and practice for accounting based on core competence [J]. Finance and Accounting Monthly, 2010; (27) :103-105. 